\title{
Transmission of Pantoea ananatis, Causal Agent of Center Rot of Onion, by Tobacco Thrips, Frankliniella fusca
}

\author{
R. D. Gitaitis, Department of Plant Pathology, Coastal Plain Experiment Station, University of Georgia, Tifton \\ 31793; R. R. Walcott, Department of Plant Pathology, University of Georgia, Athens 30602; M. L. Wells, Coopera- \\ tive Extension Service, University of Georgia, 125 Pine Ave., Albany 31701; J. C. Diaz Perez, Department of Hor- \\ ticulture, Coastal Plain Experiment Station, University of Georgia, Tifton 31793-0748; and F. H. Sanders, Depart- \\ ment of Plant Pathology, Coastal Plain Experiment Station, University of Georgia, Tifton 31793
}

\begin{abstract}
Gitaitis, R. D., Walcott, R. R., Wells, M. L., Diaz Perez, J. C., and Sanders, F. H. 2003. Transmission of Pantoea ananatis, causal agent of center rot of onion, by tobacco thrips, Frankliniella fusca. Plant Dis. 87:675-678.

Center rot of onion, caused by Pantoea ananatis, was first reported on onion in Georgia in 1997 and has continued to reduce yields and cause postharvest losses. In a previous study, we developed a nondestructive assay that demonstrated an association between $P$. ananatis and approximately $10 \%$ of the tobacco thrips, Frankliniella fusca, surveyed. In this study, we report that all strains of $P$. ananatis, isolated from surface-sterilized, crushed thrips, were pathogenic when inoculated onto greenhouse-grown onion plants. Furthermore, when 6 to 12 thrips harboring populations of $P$. ananatis of $1 \times 10^{3} \mathrm{CFU} \mathrm{m}{ }^{-1}$ or greater were placed on healthy onion seedlings to feed, disease transmission occurred in $52 \%$ of the plants challenged. Incubation periods ranged from 4 to 9 days. Bacteria isolated from symptoms typical of those associated with center rot were characterized and identified as $P$. ananatis. In contrast, an equal number of plants remained healthy for up to 28 days after being exposed to the same number of tobacco thrips that were identified as being free of $P$. ananatis.
\end{abstract}

Additional keywords: Allium cepa

Center rot of onion, caused by Pantoea ananatis (Serrano) Mergaret, was first described in Georgia in 1997. The disease was devastating and accounted for $100 \%$ loss in some fields (15). In addition to onions, the bacterium has been reported to infect cantaloupe, Eucalyptus, honeydew melons, muskmelons, pineapple, and Sudangrass $(1,4-6,26,27,36)$. It also has been associated with the condition known as graywall of tomato (28). Since 1997, $P$. ananatis has been responsible for sporadic losses in onion in Georgia, but it has been particularly severe in certain late-maturing cultivars. Symptoms generally include white streaks with water-soaked margins running the length of the leaf. Over time, the streaks may darken to a light brown or gray color. Symptoms first appear as one or two infected leaves in the center of the plant. As the disease develops, severely infected plants may wilt. Unfortunately, the invasion of bulb tissues does not appear to be related to the degree of foliar disease severity. Asymptomatic, mildly diseased,

Corresponding author: R. D. Gitaitis

E-mail: Gitaitis@tifton.uga.edu

Accepted for publication 20 January 2003.

Publication no. D-2003-0324-03R

(C) 2003 The American Phytopathological Society and severely diseased plants are all prone to postharvest rots associated with $P$. ananatis. By itself, $P$. ananatis does not cause an extensive amount of damage, and based on results from growth on CVP medium (7), it does not have pectinolytic enzymes. However, infected bulbs frequently are colonized by secondary microbes that liquefy tissues and produce a foul odor. Consequently, center rot is not only an important disease in the field, but also is of great consequence as part of a postharvest disease complex.

Our goal is to develop management strategies that reduce losses caused by center rot. One approach to control plant diseases is to identify and eliminate the source of inoculum (32). To date, we have identified seed (33) and weeds (13) as potential sources of inocula. In previous work, we demonstrated an association between tobacco thrips Frankliniella fusca and $P$. ananatis as a member of its internal microflora, and described a nondestructive sampling method to identify thrips with internal populations of bacteria (37). In this study, we provide evidence for thrips transmitting virulent strains of $P$. ananatis to onion. Although thrips transmit viruses such as Tomato spotted wilt virus (2), to our knowledge this is the first report of members of the order Thysanoptera serving as a vector of a plant pathogenic bacterium.

\section{MATERIALS AND METHODS}

Collection of tobacco thrips. Adult tobacco thrips were collected from onion plants at the University of Georgia, Blackshank Research Farm in Tifton, on 17, 19, 20, and 30 April and 2 May 2001, and on 29 January, 6 February, 6, 12, 14, 19, and 27 March, and 15 April 2002. Adult tobacco thrips also were collected from peanut blossoms from the Rigdon Farm on 20 September 2001 and at the Blackshank Farm on 7 August and from peanut leaves at the Blackshank Farm on 14 August 2002.

Identification of positive thrips. Peanut leaflets were collected from thrips-free plants grown in the greenhouse or in growth chambers and processed as previously described (37). Briefly, leaflets were soaked in $10 \%$ sodium hypochlorite for 30 $\mathrm{s}$ and then transferred to $70 \%$ ethanol for $30 \mathrm{~s}$. After rinsing in sterile PBST (phosphate-buffered saline, $0.01 \mathrm{M} \mathrm{K} \mathrm{K}_{2} \mathrm{HPO}_{4}$, $0.85 \% \mathrm{NaCl}$, and $0.02 \%$ Tween 20 ) at $\mathrm{pH}$ 7.0 , leaflets were placed in labeled $1.5-\mathrm{ml}$ microcentrifuge tubes. Adult thrips were surface-sterilized using the same procedures and placed individually into tubes to feed on peanut leaflets. After $24 \mathrm{~h}$, thrips were removed and maintained in new, sterile microcentrifuge tubes and labeled accordingly, i.e., matching the corresponding tube containing the leaflet from which they were removed. Sterile PBST $(1.0 \mathrm{ml})$ was added to the tubes containing peanut leaflets. Tubes were vortexed for $30 \mathrm{~s}$, and $10^{-2}$-fold serial dilutions (1:9) were made in PBS. Aliquots of $0.1 \mathrm{ml}$ were spread onto tryptic soy broth agar (TSBA) plates and incubated at $28^{\circ} \mathrm{C}$ for $48 \mathrm{~h}$. As determined previously (37), thrips from leaflets with populations of $P$. ananatis of $1 \times 10^{3}$ $\mathrm{CFU} \mathrm{ml}{ }^{-1}$ or greater were selected as positive. To verify the surface sterilization of thrips, $1.0-\mathrm{ml}$ samples from five replicates of 10 thrips processed as above were plated onto TSBA. After the surface rinse was removed and plated, thrips were placed in another 1.0-ml tube of PBST, triturated as described previously (37), and the resulting suspension plated on TSBA. Bacterial colonies were counted after $48 \mathrm{~h}$ incubation at $28^{\circ} \mathrm{C}$. Numbers of bacterial colonies isolated from external surfaces of thrips bodies and from crushed thrips were compared. 
Isolation and cultivation of $P$. ananatis from surface-sterilized thrips. A subset of adult tobacco thrips $(n=16)$ were surface-sterilized, identified as positive for carrying populations of $P$. ananatis by the peanut leaf assay described above, and crushed in $1.0 \mathrm{ml}$ of PBST. The resulting suspensions were used to prepare serial dilutions (1:9) in PBST. Aliquots $(0.1 \mathrm{ml})$ from the resulting suspensions were spread on the surface of TSBA plates. Plates were incubated at $28^{\circ} \mathrm{C}$ for 5 days, and colonies were enumerated. Single colonies of $P$. ananatis were selected, purified by sequential transfers on TSBA, and stored in 15\% glycerol at $-72^{\circ} \mathrm{C}$ as strains obtained from thrips. These strains were used to inoculate onion plants grown in the greenhouse, as previously described $(13,15)$.

Transmission studies. A subset of adult tobacco thrips was surface-sterilized and identified as positive or negative for carrying populations of $P$. ananatis by the peanut leaf assay. Onions were grown in the greenhouse as previously described $(13,15)$. For the transmission studies, 10cm-diameter plastic pots containing 6- to 12-week-old onions were carefully placed into clear, plastic, 3.78-liter jars to avoid damaging leaves. Jars were tightly capped with rubber bands and $15 \times 15 \mathrm{~cm}$ pieces of lightweight, polyester material with a
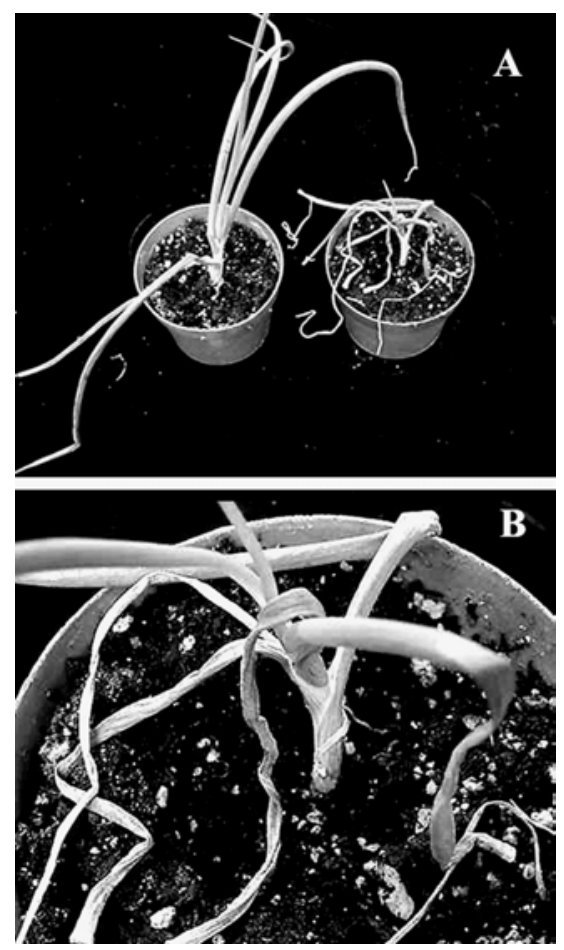

Fig. 1. Transmission of Pantoea ananatis to onion, Allium cepa, by tobacco thrips, Frankliniella fusca. A, Side-by-side comparison of plants challenged by tobacco thrips identified either as lacking (left) internal populations of $P$. ananatis or harboring (right) populations greater than $1 \times 10^{3} \mathrm{CFU} \mathrm{ml}^{-1}$. B, Higher magnification of plant on right, to which tobacco thrips transmitted the bacterium and which displays typical center rot symptoms. knit too fine for thrips to escape. Depending on the number of positive thrips detected, 6 to 12 thrips were placed on individual onion plants. A similar number of thrips testing negative for $P$. ananatis were placed on separate plants to serve as a negative control. Thrips testing negative for $P$. ananatis were used in the transmission studies as negative controls. Again, depending on the number of positive thrips detected, two to five plants were used in each trial, with a corresponding number of plants used as negative controls. Jars containing test plants were maintained in the laboratory at approximately $27^{\circ} \mathrm{C}$ under plant-growth light units (Helios, Percival Manufacturing Co., Boone, IA). Transmission trials were repeated five times. Thrips collected from onion plants were used in trials one through three, and when onions were unavailable, thrips collected from peanut plants were used for trials four and five.

Characterization and identification of bacteria. Bacteria from crushed thrips, from peanut leaflets from the disk assay, or from symptomatic plants after thrips feeding were isolated onto plates of TSBA. Suspect colonies were identified as previously described $(13,15)$. Briefly, bacterial colonies were characterized by the presence of a yellow pigment and morphology on TSBA, Gram-reaction, utilization of glucose in an oxidative and fermentative manner, fatty acid profile, indole reaction, and nitrate reductase reaction (13). In addition, PCR was conducted using primers PanITS1 and EC5, described previously (13), which amplify specific DNA segments of the $16 \mathrm{~S}-23 \mathrm{~S}$ rDNA internal transcribed spacer (ITS) region of $P$. ananatis. Finally, strains were inoculated onto onion seedlings and pathogenicity was confirmed as previously described $(13,15)$.

\section{RESULTS}

Isolation of $P$. ananatis from surfacesterilized, crushed thrips. Populations of $P$. ananatis recovered from surfacesterilized, crushed thrips were similar to what was recovered previously (37). In a subset of thrips $(n=16), P$. ananatis populations ranged from $1.1 \times 10^{3} \mathrm{CFU} \mathrm{ml}^{-1}$ to
$1.3 \times 10^{5} \mathrm{CFU} \mathrm{ml}^{-1}$, and the mean was 1.64 $\times 10^{4} \mathrm{CFU} \mathrm{ml}{ }^{-1}$. Colonies recovered from surface-sterilized, crushed thrips were yellow, gram negative, utilized glucose as a facultative anaerobe, positive for indole, and negative for nitrate reductase. These characteristics are typical for $P$. ananatis and help differentiate it from most strains of similar species such as $P$. stewartii and $P$. agglomerans. In addition, thrips strains had a fatty acid profile typical of $P$. ananatis, and their DNA from the ITS region amplified with the $P$. ananatis primers. All strains of $P$. ananatis isolated from thrips $(n=7)$ produced typical center rot symptoms when inoculated onto greenhouse-grown onion seedlings. Onion plants inoculated with sterile water remained healthy.

Transmission studies. Tobacco thrips successfully transmitted $P$. ananatis, and typical center rot symptoms developed in $52 \%$ of the plants challenged in four out of the five trials (Fig. 1). Of those plants developing center rot, the mean incubation period was 6.75 days from the time plants were first exposed to thrips (Table 1). All plants challenged with thrips deemed negative for $P$. ananatis remained healthy up to 28 days after exposure to thrips, at which time tests were terminated. Colonies recovered from onion plants with typical center rot symptoms were yellow, gram negative, utilized glucose as a facultative anaerobe, positive for indole, and negative for nitrate reductase. In addition, they had a fatty acid profile typical of $P$. ananatis, and their DNA from the ITS region amplified with the $P$. ananatis primers.

\section{DISCUSSION}

We previously demonstrated an association between $P$. ananatis and the internal microflora of tobacco thrips (37). In this study, we demonstrated that the bacteria recovered from surface-sterilized, crushed thrips were pathogenic to onion. Furthermore, we demonstrated that thrips, identified by the peanut leaf assay as harboring populations of $P$. ananatis, served as a vector of this plant-pathogenic bacterium and succeeded in transmitting the disease to $52 \%$ of the plants challenged in $80 \%$ of

Table 1. Results of transmission of Pantoea ananatis to onion, Allium cepa, by surface-sterilized tobacco thrips, Frankliniella fusca

\begin{tabular}{|c|c|c|c|c|c|c|c|}
\hline \multirow[b]{2}{*}{ Trial } & \multirow[b]{2}{*}{ Source $^{b}$} & \multicolumn{3}{|c|}{ + Thrips ${ }^{\mathrm{a}}$ transmission data } & \multicolumn{3}{|c|}{ - Thrips ${ }^{\mathrm{a}}$ transmission data } \\
\hline & & $\begin{array}{c}\text { Thrips }^{c} \\
\text { (no.) }\end{array}$ & $\begin{array}{c}\text { Transmission } \\
(\%)\end{array}$ & $\begin{array}{c}\text { Days }^{d} \\
\text { (no.) }\end{array}$ & $\begin{array}{c}\text { Thrips } \\
\text { (no.) }\end{array}$ & $\begin{array}{c}\text { Transmission } \\
(\%)\end{array}$ & $\begin{array}{c}\text { Days }^{d} \\
\text { (no.) }\end{array}$ \\
\hline 1 & $\mathrm{O}$ & 9 & 50 & 7 & 9 & 0 & 28 \\
\hline 2 & $\mathrm{O}$ & 6 & 0 & 28 & 6 & 0 & 28 \\
\hline 3 & $\mathrm{O}$ & 6 & 50 & 7 & 6 & 0 & 28 \\
\hline 4 & $\mathrm{P}$ & 12 & 60 & 9 & 12 & 0 & 28 \\
\hline 5 & $\mathrm{P}$ & 6 & 100 & 4 & 6 & 0 & 28 \\
\hline
\end{tabular}

${ }^{a}+$ or - Indicates whether or not $P$. ananatis was detected in the peanut leaflet disk assay.

b Source of thrips from $\mathrm{O}$ (onion) or $\mathrm{P}$ (peanut).

c Values indicate how many adult thrips were placed on each onion plant.

d Indicates either number of days until symptoms developed or, if no symptoms developed, number of days plants were maintained until the test was terminated. 
the five trials attempted. In contrast, disease never developed the negative controls, i.e., onion plants infested with thrips deemed negative for the bacterium. These results further support the peanut leaf disk assay (37) as a nondestructive technique for identifying thrips that harbor virulent populations of $P$. ananatis. Peanut leaves were used in the assay primarily on the basis of convenience, because a thrips colony, maintained at our research station for use in tomato spotted wilt studies, already existed on peanut plants. Furthermore, peanut grows faster than onion, and detached peanut leaves are easier to disinfect, fit inside the plastic chambers, and have greater structural integrity when bacteria are washed off the surface.

Ingress and infection are crucial events in the life cycle of a plant pathogen; thus the identification of a specific infection court and transmission of a pathogen may have implications for the development of disease management strategies. There is no evidence for direct penetration of intact plant tissues by bacteria. Consequently, natural openings and wounds are important to bacterial ingress into plants $(19,31)$. Closely related phytopathogenic bacteria such as $P$. stewartii and $P$. tracheiphila are known to overseason in the gut of, and are vectored by, corn flea beetles and cucumber leaf beetles, respectively $(20,38)$. In addition, saprophytic strains of an Erwinia species were reported to inhabit and proliferate in the hindgut of western flower thrips, Frankliniella occidentalis $(8,9)$. The authors never fully identified the bacterium to species, but suggested it was closely related to Enterobacter agglomerans. The taxonomy of this species is in flux, and the bacterium has been placed into the Enterobacter agglomerans-Erwinia herbicola complex. Some have classified the group into the genus Pantoea $(24,30)$, which is the convention that we follow in this paper. In any account, $P$. agglomerans has been reported not only in association with thrips but also with grasshoppers $(10,23)$, termites (25), beetles (3), aphids (18), and flies $(21,22)$. There is disagreement within the scientific community as to whether these relationships are transient (21) or are examples of facultative symbionts $(18,22)$. The majority of these studies do not go into depth regarding the population dynamics of the bacterium and therefore are inconclusive as to the exact relationship between insect and bacterium.

In addition to its close relatives, $P$. ananatis also has been reported as an inhabitant of the gut of insects. It has been reported from brown planthoppers (Nilaparvata lugens) (34) and mulberry pyralids (35). This is not surprising since the genus Pantoea is classified in the family Enterobacteriaceae, which contains Escherichia coli, the quintessential gut bacterium. However, none of the reports indicated that the insects served as a vector or that the bacteria caused a plant disease. Rather, the studies dealt with the insect and the bacterium either as a symbiont or as an entity that reduced the hardiness of the insect.

In this paper, we report the first instance of thrips serving as a vector for a plant-pathogenic bacterium. Transmission by thrips could explain a number of observations we have made regarding the epidemiology of center rot of onion. For example, in some field plots we observed a primary disease gradient, which was present in two separate years (12). Although gradients could be explained by several factors, such as transmission by mechanical equipment (16) or a local source of inoculum such as weeds $(16,17)$, similar disease gradients also were observed in pepper fields where plants were infected with tomato spotted wilt (14), which also is transmitted by thrips. A gradient would not likely exist if the inoculum was seedborne or windblown from a great distance.

Another observation that could be explained by the thrips transmission theory is that center rot of onion is unaffected by spraying with fixed-copper bactericides. In lab surveys, $P$. ananatis is just as sensitive to copper compounds as Pseudomonas viridiflava (39), which causes bacterial streak of onion but is controlled quite effectively with copper bactericides (11). This discrepancy could be explained if $P$. viridiflava relied on epiphytic colonization of onion leaves and ingress through natural openings such as stomata. Under those circumstances, $P$. viridiflava would come into contact with a protective barrier of copper compounds sprayed on onion foliage. On the other hand, if $P$. ananatis was transmitted by thrips, the bacterium would be less likely to be exposed to bactericides in the infection court, as those tissues would not be covered by a pesticide applied in a conventional manner. Thrips colonize onions by feeding on succulent, growing tissues near the basal meristem of leaves. In the primary area of thrips feeding, the base of the leaf whorl, the leaves are folded upon one another creating several tightly wound or coiled layers. It is difficult if not impossible to protect this area with surface-protectant bactericides. It is likely that thrips feeding in this area create wounds that become contaminated with feces containing $P$. ananatis. Also, it is common for free water to flood and congest the tissues of the onion whorl. The presence of free water would enhance bacterial infection and movement up the leaf. Water congestion and other predisposing factors may increase the transmission rate that we observed under laboratory conditions. Also, the transmission rate in the field may be higher than what we observed in the laboratory. However, even at a transmission rate of $52 \%$ with an average of eight thrips per plant, the transmission rate is high enough to cause concern and could account for disease levels observed in the field.

Finally, the appearance of the first symptoms of center rot and the development of disease over time may correspond to populations of thrips and the damage caused by thrips. Todd et al. (29) reported that seasonal fluctuations occurred in thrips populations and that peak populations of $F$. fusca adults in peanuts occurred 10 to 20 days after planting in April. This time period would correspond with peak levels of incidence of center rot of onion. However, further work is required to determine if the patterns of thrips' populations in peanut also exist in onion and are significant to development of center rot epidemics.

A number of other questions need to be answered before successful control measures can be developed. For instance, are other thrips species capable of harboring and transmitting $P$. ananatis? What life stage(s) of the thrips acquires the bacterium? Does the bacterium have a transient or permanent relationship with thrips? Does $P$. ananatis have a detrimental effect on tobacco thrips fecundity and longevity? Are the preferred location of tobacco thrips feeding and the infection court for $P$. ananatis the same location? Finally, do thrips play a role in secondary spread if the primary inoculum comes from seed or weeds?

\section{ACKNOWLEDGMENTS}

Funding for this research was provided by the Vidalia Onion Committee and USDA/CSREES Grant No. 99-34389-7437, entitled "Integrated Disease Management to Improve the Quality of Sweet Onions in Georgia".

\section{LITERATURE CITED}

1. Azad, H. R., Holmes, G. J., and Cooksey, D. A. 2000. A new leaf blotch disease of sudangrass caused by Pantoea ananas and Pantoea stewartii. Plant Dis. 84:973-979.

2. Bald, J. G., and Samuel, G. 1931. Investigations on "spotted wilt" of tomatoes. II. CSIRO Aust. Bull. 54.

3. Bridges, J. R. 1981. Nitrogen-fixing bacteria associated with bark beetles. Microbial Ecol. 7:131-137.

4. Bruton, B. D., Wells, J. M., and Lester, G. E. 1986. Pathogenicity of Erwinia ananas muskmelons in Texas. (Abstr.) Phytopathology 76:1136.

5. Bruton, B. D., Wells, J. M., Lester, G. E., and Patterson, C. L. 1991. Pathogenicity and characterization of Erwinia ananas causing a postharvest disease of cantaloupe fruit. Plant Dis. 75:180-183.

6. Coutinho, T. A., Preisig, O., Mergaert, J., Cnockaert, M. C., Riedel, K.-H., Swings, J., and Wingfield, M. J. 2002. Bacterial blight and dieback of Eucalyptus species, hybrids, and clones in South Africa. Plant Dis. 86:20-25.

7. Cuppels, D. and A. Kelman, 1974. Evaluation of selective media for isolation of softrot bacteria from soil and plant tissue. Phytopathology 64:468-475.

8. de Vries, E. J., Breeuwer, J. A. J., Jacobs, G., and Mollema, C. 2001. The association of western flower thrips, Franliniella occidentalis, with a near Erwinia species gut bacteria: Transient or permanent? J. Invertebr. Pathol. 77:120-128.

9. de Vries, E.J., G. Jacobs, and J.A.J. Breeuwer. 
2001. Growth and transmission of gut bacteria in the western flower thrips, Frankliniella occidentalis. J. Invertebr. Pathol. 77:129-137.

10. Dillon, R. J., and Charnley, A. K. 1995. Chemical barriers to gut infection in the desert locust: In vivo production of antimicrobial phenols associated with the bacteria Pantoea agglomerans. J. Invertebr. Pathol. 66:7275 .

11. Gitaitis, R. 1998. Bacteriology Report. Pages 11-14 in: Georgia Onion 1998 Research - Extension Report. B. W. Maw, ed. The University of Georgia, Tifton Campus, Tifton.

12. Gitaitis, R., Diaz-Perez, J. C., Walcott, R., and Sanders, H. 2002. Effects of mulch and irrigation on center rot of onion. (Abstr.) Phytopathology 92:S149.

13. Gitaitis, R., Walcott, R., Culpepper, S., Sanders, H., Zolobowska, L., and Langston, D. 2002. Recovery of Pantoea ananatis, causal agent of center rot of onion, from weeds and crops in Georgia, USA. Crop Prot. 21:983989.

14. Gitaitis, R. D., Dowler, C. C., and Chalfant, R. B. 1998. Epidemiology of tomato spotted wilt in pepper and tomato in southern Georgia. Plant Dis. 82:752-756.

15. Gitaitis, R. D., and Gay, J. D. 1997. First report of a leaf blight, seed stalk rot, and bulb decay of onion by Pantoea ananas in Georgia. Plant Dis. 81:1096.

16. Gitaitis, R. D., Stall, R. E., and Strandberg, J. O. 1978. Dissemination and survival of Pseudomonas alboprecipitans ascertained by disease distribution. Phytopathology 68:227231.

17. Gregory, P. H. 1968. Interpreting plant disease dispersal gradients. Annu. Rev. Phytopathol. 6:189-212.

18. Harada, H., Oyaizu, H., and Ishikawa, H. 1996. A consideration about the origin of aphid intracellular symbiont in connection with gut bacterial flora. J. Gen. Appl. Microbiol. 42:17-26.

19. Layne, R. E. C. 1967. Foliar trichomes and their importance as infection sites for Corynebacterium michiganense on tomato. Phytopathology 57:981-985.

20. Leach, J. G. 1964. Observations on cucumber beetles as vectors of cucurbit wilt. Phyto- pathology 54:606-607.

21. Lloyd, A. C., Drew, R. A. L., Teakle, D. S., and Hayward, A. C. 1986. Bacteria associated with some Dacus species (Diptera:Tephritidae) and their host fruit in Queensland. Aust. J. Biol. Sci. 39:361-368.

22. MacCollom, G. B., Lauzon, C. R., Payne, E. B., and Currier, W. W. 1994. Apple maggot (Diptera: Tephritidae) trap enhancement with washed bacterial cells. Environ. Entomol. 23:354-359.

23. Mead, L. J., Khachatourians, G. G., and Jones, G. A. 1988. Microbial ecology of the gut in laboratory stocks of the migratory grasshopper, Melanoplus sanguinipes (Fab.) (Orthoptera:Acrididae). Appl. Environ. Microbiol. 54:1174-1181.

24. Mergaert, J., Verdonck, L., and Kersters, K. 1993. Transfer of Erwinia ananas (synonym, Erwinia uredovora) and Erwinia stewartii to the genus Pantoea emend. as Pantoea ananas (Serrano 1928) comb. nov. and Pantoea stewartii (Smith 1898) comb. nov., respectively, and description of Pantoea stewartii subsp. indologenes subsp. nov. Int. J. Syst. Bacteriol. 43:162-173.

25. Potrikus, C. J., and Breznak, J. A. 1977. Nitrogen-fixing Enterobacter agglomerans isolated from guts of wood-eating termites. Appl. Environ. Microbiol. 33:392-399.

26. Schwartz, H. F, and Otto, K. 2000. First report of a leaf blight and bulb decay of onion by Pantoea ananitas in Colorado. Plant Dis. 84:808.

27. Serrano, F. B. 1928. Bacterial fruitlet brownrot on pineapple in the Philippines. Philippine J. Sci. 36:271-305

28. Stall, R. E., Alexander, L. J., and Hall, C. B. 1969. Effect of tobacco mosaic virus and bacterial infections on occurrence of graywall of tomato. [Erwinia ananas]. Fla. State Hortic. Soc. Proc. 81:157-161.

29. Todd, J. W., Culbreath, A. K., Chamberlin, J. R., Beshear, R. J., and Mullinix, B. G. 1995. Colonization and population dynamics of thrips in peanuts in the southern United States. Pages 453-460 in: Thrips Biology and Management. Proc. 1993 Int. Conf. Thysanoptera: Towards Understanding Thrips Management. NATO ASI Series A, Life Sciences,
276. B. L. Parker, M. Skinner, and T. Lewis, eds. Plenum Press, NY

30. Truper, H. G., and DeClari, L. 1997. Taxonomic note: Necessary correction of specific epithets formed as substantives (nouns) "in apposition". Int. J. Syst. Bacteriol. 47:908909

31. Vakili, N. G. 1967. Importance of wounds in bacterial spot (Xanthomonas vesicatoria) of tomatoes in the field. Phytopathology 57:1099-1103.

32. Vanderplank, J. E. 1963. Plant Diseases: Epidemics and Control. Academic Press, New York.

33. Walcott, R. R., Gitaitis, R. D., Castro, A. C Sanders, F. H., Jr., and Diaz-Perez, J. C. 2002 Natural infestation of onion seed by Pantoea ananatis, causal agent of center rot. Plant Dis. 86:106-111.

34. Watanabe, K., Kawakita, H., and Sato, M. 1996. Epiphytic bacterium, Erwinia ananas, commonly isolated from rice plants and brown planthoppers (Nilaparvata lugens) in hopperburn patches. Appl. Entomol. Zool. 31:459-462.

35. Watanabe, K., and Sato, M. 1999. Gut colonization by an ice nucleation active bacterium, Erwinia (Pantoea) ananas reduces the cold hardiness of mulberry pyralid larvae. Cryobiology 38:281-289.

36. Wells, J. M., Sheng, W. S., Ceponis, M. J and Chen, T. A. 1987. Isolation and characterization of strains of Erwinia ananas from honeydew melons. Phytopathology 77:511514.

37. Wells, M. L., Gitaitis, R. D., and Sanders, F. H. 2002. The Association of tobacco thrips. Frankliniella fusca, (Thysanoptera:Thripidae) with two species of bacteria of the genus Pantoea. Ann. Entomol. Soc. Am. 95:719-723.

38. Woods, T. L., Israel, H. W., and Sherf, A. F. 1981. Isolation and partial characterization of a bacteriophage of Erwinia stewartii from the corn flea beetle Chaetocnema pulicaria. Prot. Ecol. 3:229-236.

39. Zolobowska, L., Gitaitis, R., Sanders, H., Langston, D., and Purvis, A. 2000. Copper tolerance in strains of Pantoea ananatis, causal agent of center rot of onion, in Georgia. (Abstr.) Phytopathology 90:S130. 